\title{
Incidental Traumatic Pseudoaneurysm of the Middle Meningeal Artery: Case Report and Literature Review
}

\section{Orta Meninjial Arterin Tesadüfen Bulunmuş Travmatik Psödoanevrizmast: Olgu Sunumu ve Literatürün Gözden Geçirilmesi}

Khursheed NAYIL, Altaf RAMZAN, Rumana MAKHDOOMI, Abrar WANI, Javeed ZARGAR, Feroze SHAHEEN

SKIMS, Department of Neurosurgery, Kashmir, India

Correspondence address: Khursheed NAYIL / E-mail: nkhursh@rediffmail.com

\begin{abstract}
Traumatic pseudoaneurysm of the middle meningeal artery is rare and is associated with high mortality. Skull fracture is usually an associated feature of this entity. An elderly male was brought to our hospital in a stage of coma. The details of ictus were not known. The Glasgow coma scale score was 9/15. Examination revealed a pseudo-aneurysm arising from the posterior branch of the left middle meningeal artery which was excised. The case is presented for its rarity and its characteristic radiology. Traumatic pseudoaneurysm of middle meningeal artery is rare. It is important to recognize this treatable entity.
\end{abstract}

KEYWORDS: Skull fracture, Extradural hematoma, Pseudoaneurysm, Middle meningeal artery

öz

Orta meninjial arterin travmatik psödoanevrizması nadir görülmekle beraber yüksek mortalite ile seyreden bir olaydır. Kafatasında kırık görülmesi orta meninjial arterin travmatik psödoanevrizmasının bir özelliğidir. Yaşlı erkek hasta hastanemize koma halinde getirildi. Hastanın bilinç kaybı ile ilgili bir bilgi elde edilemedi. Hastanın Glasgow Koma ölçeği 9/15'di. Hastanın muayenesinde sol orta meninjial arterin arka dalından kesilmiş olduğu görüldü. Olgu nadir görülmesi ve karakteristik radyolojik özelliği nedeni ile sunulmuştur. Orta meninjial arterin psödoanevrizması nadir görülen ve tanı konulunca tedavi edilebilen bir patolojidir.

ANAHTAR SÖZCÜKLER: Kafatası kırı̆ı, Ekstradural hematom, Psödoanevrizma, Orta meninjial arter

\section{INTRODUCTION}

Traumatic pseudoaneurysms of the middle meningeal artery are rare lesions accounting for less than $1 \%$ of all intracranial aneurysms (2). The aneurysms are usually associated with skull fracture (3). The overall mortality is $20 \%$ (3) and the usual presentation is extradural hematoma but subdural, subarachnoid and intra cerebral hematomas are also known (1).

\section{CASE REPORT}

\section{Presentation}

A 50-year-old male was brought to he Accident and Emergency department of our hospital in a state of stupor. The details of ictus were not known. Physical examination revealed abrasions on forehead. The Glasgow coma scale score was $9 / 15$. There was no lateralizing sign.

\section{Imaging}

CT scan of the head revealed multiple brain contusions especially of the temporal lobes with diffuse brain edema.
There was a lot of cisternal blood in the right side of the chiasmatic cistern (Figure 1). A suspicion of aneurysmal rupture with loss of consciousness, subsequent fall and injury to the head was made. MR angiography of the intracranial vessels was performed and revealed a $2 \times 2 \mathrm{~cm}$ aneurysm arising from the posterior branch of the left middle meningeal artery (Figure 2). Skull radiograph lateral view showed a linear non-depressed fracture running across the groove from the posterior branch of the middle meningeal artery (Figure 3).

\section{Operation}

A temporal craniotomy was performed. There was no extradural hematoma. The termination of the posterior branch of middle meningeal artery was dilated to form a $2 \times 2 \mathrm{~cm}$ false aneurysm. The aneurysm was excised in toto and the feeding vessel was cauterized. There was no extension of the aneurysmal sac intradurally.

\section{Post-operative period}

The patient was managed conservatively for contusion and 


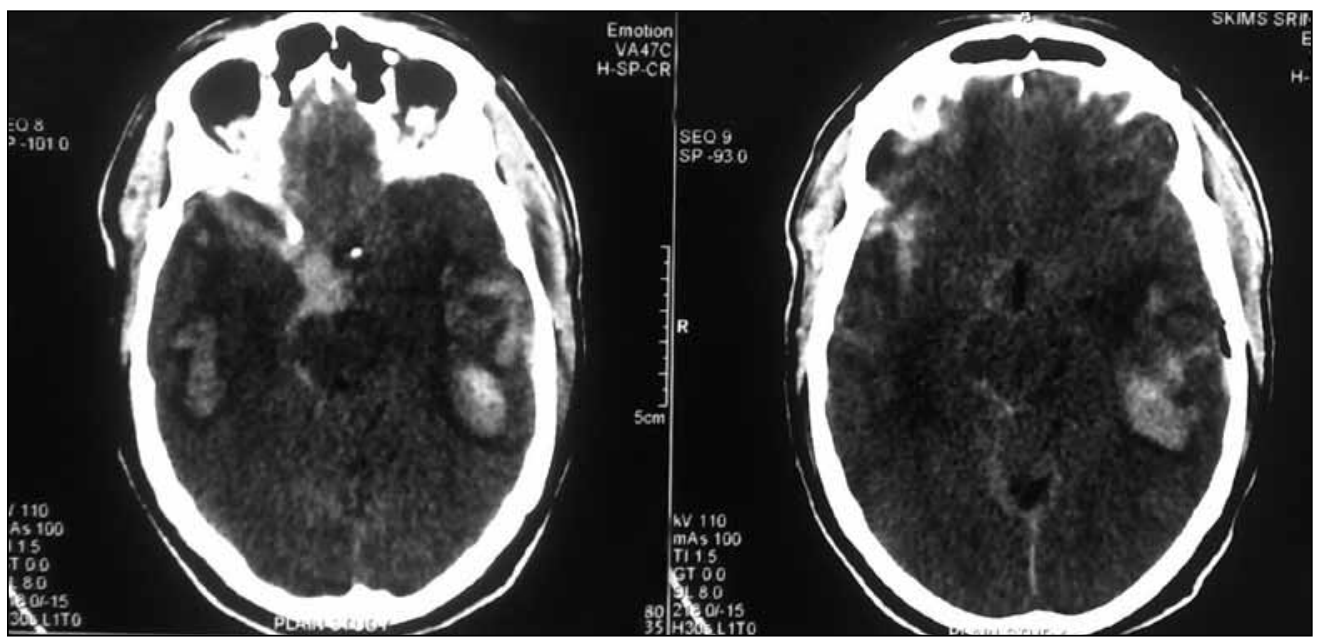

Figure 1: CT scan head showing multiple brain contusions with blood in the chiasmatic cistern.

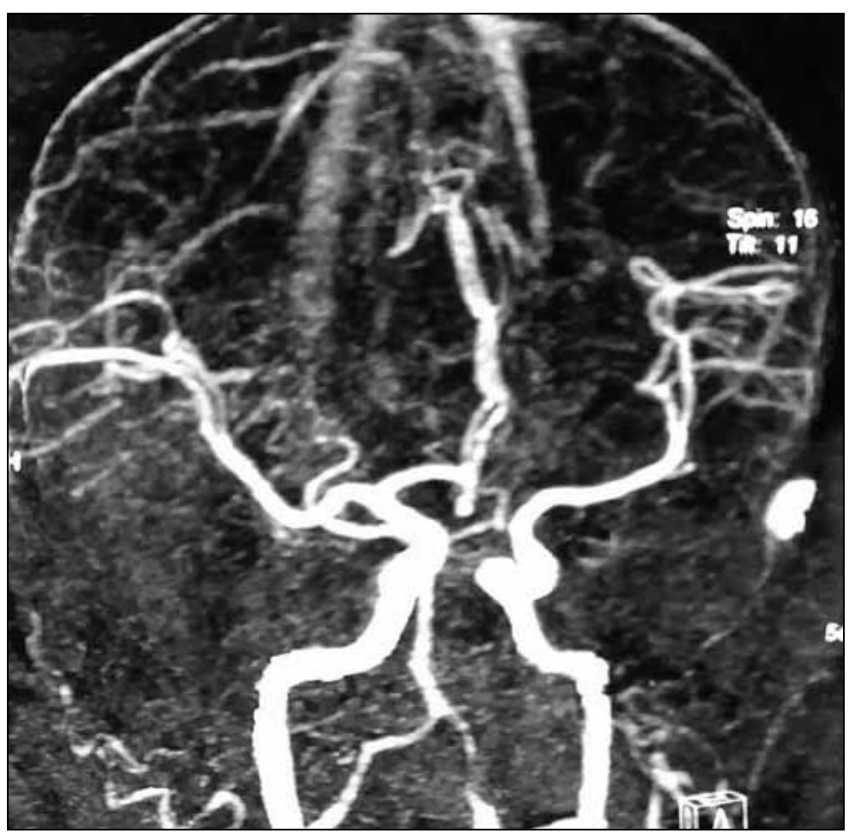

Figure 2: MR angiogram showing an aneurysm arising from the middle meningeal artery.

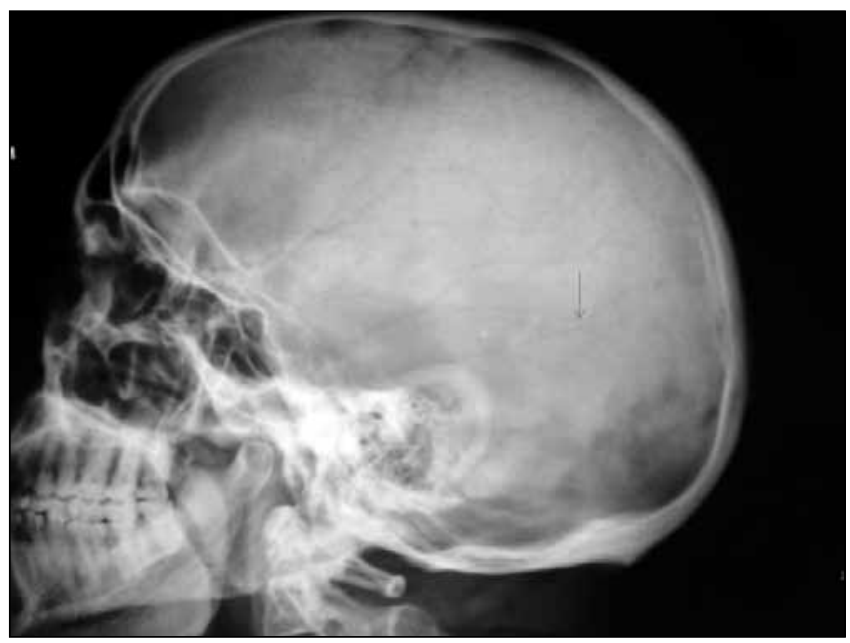

Figure 3: Skull X-ray revealing a fracture line going across the temporal bone.

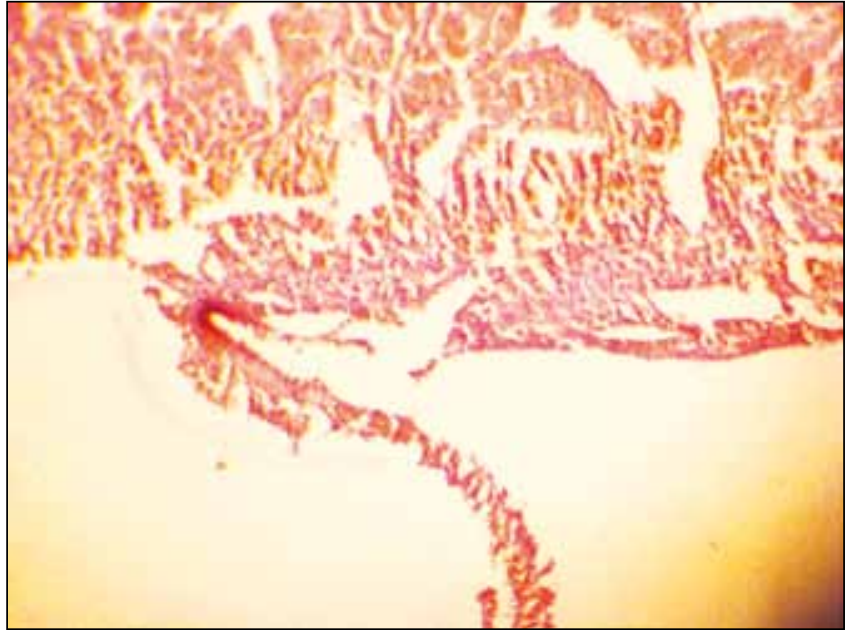

Figure 4: Photomicrograph $(\mathrm{H} \& \mathrm{E}, \mathrm{x} 20)$ showing a thrombus in the vessel with reflected wall of the pseudoaneurysm.

diffuse brain edema. The patient made a good post operative recovery and is on follow up.

\section{Histopathology}

Histopathology of the lesion was consistent with pseudoaneurysm (Figure 4).

\section{DISCUSSION}

True saccular aneurysms of the middle meningeal artery are rare and are seen in Paget's disease, dural AVMs, Moyamoya disease and meningiomas (10).The first case of traumatic pseudoaneurysm of the middle meningeal artery was reported by Schulze in 1957 (15). About 85\% of traumatic pseudoaneurysms are found in the temporal region (4). A fracture line is found in $92 \%$ of these cases $(6,7)$. The aneurysm may be located in the weakest part of vessel wall and not necessarily beneath the fracture line. Traumatic pseudo aneurysms usually show an absent true neck, irregular wall, peripheral location and delayed filling and emptying( 6). Freckman et al. found middle meningeal artery aneurysms in 
$4 \%$ and AV fistula of middle meningeal artery in $1.8 \%$ after reviewing 892 middle meningeal arteries in 446 cerebral angiograms in head injury patients (5). The interval between trauma and pseudoaneurysm rupture ranges from 1 day to 1 year $(3,14,17)$. Various treatment options are available, ranging from craniotomy and excision $(9,17)$, embolization $(8,13)$ to conservative management $(12,16,18,19)$.

The natural history of these lesions is not well known as external carotid angiography is not performed routinely for head injuries. The possible pathogenesis is that the initial tear in the intima is sealed off by a clot, and in time progresses to form a false aneurysm. The pseudoaneurysm can rupture and give rise to extradural, subdural, and subarachnoid or intra parenchymal bleeds (1). In our patient, the CT angiogram was done 48 hours after the trauma. A small tear in the intima at the time of injury could have been there which subsequently was sealed off by the clot. Intraoperatively, we could see the terminal pseudoaneurysmal dilatation of the middle meningeal artery which was covered by a clot.

To date, most of the cases of traumatic pseudoaneurysm of middle meningeal artery that have been reported were symptomatic because of the secondary effects of this lesion; however our case is unusual as we found the traumatic pseudoaneurysm of middle meningeal artery incidentally while we were looking for either an aneurysm from the internal carotid artery or middle cerebral artery. Our patient was totally asymptomatic for this lesion. There are only two reported cases $(14,16)$ of incidental asymptomatic traumatic pseudoaneurysm of the middle meningeal artery; our case being the third. In view of the high risk of rupture and high associated mortality, we decided to operate and excise the aneurysm, although there are four case reports of pseudoaneurysms in English literature that have been conservatively managed and where repeat angiograms have revealed complete thrombosis and obliteration of the lesions $(12,16,18,19)$.

\section{CONCLUSION}

Traumatic pseudoaneurysm of the middle meningeal artery is rare and an incidental asymptomatic lesion is even more rare. Treatment is mandatory in view of the high mortality associated with the secondary effects of this entity.

\section{REFERENCES}

1. Albert FK, Olderkoft P, Sigmund E: Subarachnoid hemorrhage and intracerebral hematoma in injury of middle meningeal artery. Zentralbl Neurochir 50:153-56, 1989

2. Bozzetto-Ambrosi P, Andrade G, Azevedo-Filho H: Traumatic pseudoaneurysm of middle meningeal artery and cerebral intra parenchymal hematoma: Case report. Surg Neurol 66(3): S29-31, 2006

3. Bruneau M, Gustin T, Zekhinini K, Gilliard C: Traumatic false aneurysm of the middle meningeal artery causing an intracerebral hemorrhage: Case report and literature review. Surg Neurol 57:174-178, 2002
4. Salazar Flores J, Vaquero J, Garcia Sola R, Rossi E, Martinez R, Martinez P, Santos H, Bravo G: Traumatic false aneurysm of the middle meningeal artery. Neurosurgery 18:200-203, 1986

5. Freckmann N, Sartor K, Herrmann HD:Traumatic arteriovenous fistula of the middle meningeal artery and neighboring veins or dural venous sinuses. Acta Neurochir (3-4):273-281, 1981

6. Holland HW, Thomas JL: Aneurysm of middle meningeal artery. Clin Radiol 16:334-338, 1965

7. Ishii R, Ueki K, Ito J: Traumatic fistula between a lacerated middle meningeal artery and a diploic vein. Case report. J Neurosurg 44(2):241, 1976

8. Kawaguchi T, Kawano T, Kaneko Y, Ooasa T, Ooigawa H, Ogasawara S: Traumatic lesions of the bilateral middle mengeal arteries- case report. Neurol Med Chir (Tokyo) 42(5):221-223, 2002

9. Kimura T, Sako K, Satoh M, Nakai H, Yonemasu Y, Takeuchi $\mathrm{E}$, Ishikura $\mathrm{H}$ : Posttraumatic pseudoaneurysm of the middle meningeal artery: A case report. No Shinkei Geka 23(11):10211025, 1995

10. Koebbe C J, Horowitz MB: A rare case of ruptured middle meningeal aneurysm causing intracerebral hematoma in a patient with Moyamoya disease. ANJR Am J Neuroradiol 25:574-576, 2004

11. Garza Mercado R, Rangel RA: Extradural hematoma associated with traumatic pseudoaneurysm of middle meningeal artery, report of two cases. Neurosurgery 5:500-503, 1979

12. Namba K, Ban S, Oda Y, Tazumi M, Ogata M: Case of traumatic false aneurysm of middle meningeal artery with epidural hematoma. Comparison with a case resulting in spontaneous thrombosis. Rinsho Shinkeigaku 12:165-170, 1972

13. Okumura $H$, Tenjin $H$, Ueda $S$ : A case of traumatic pseudoaneurysm of middle meningeal artery treated with endovascular surgery. No Shinkei Geka 26(10):929-933, 1998

14. Roski RA, Owen M, White RJ, Takaoka Y, Bellon EM: Middle meningeal artery trauma. Surg Neurol 17:200-203, 1982

15. Schulze A: Selfene verlaufs formen epiduraler hamatome. Zentrable Neurochir 17:40-47, 1957

16. Shah Q, Freidman J, Mamourian A: Spontaneous resolution of traumatic pseudoaneurysm of the middle meningeal artery. AJNR Am J Neuroradiol 26(10):2530-2532, 2005

17. Singh M, Ahmad FU, Mahapatra AK: Traumatic middle meningeal artery aneurysm causing intracerebral hematoma: A case report and review of literature. Surg Neurol 66: 321-323, 2006

18. Srinivasan A, Lesiuk $H$, Goyal M: Spontaneous resolution of posttraumatic middle meningeal artery pseudoaneurysm. AJNR, Am J Neuroradiol 27(4): 882-883, 2006

19. Tsutsumi M, Kazekawa K, Tanaka A, Ueno $Y$, Nomoto $\mathrm{Y}$, Nii K, Harada $\mathrm{H}$ : Traumatic middle meningeal artery pseudoaneurysm and subsequent fistula formation with the cavernous sinus: Case report. Surg Neurol 58:325-328, 2002 